\title{
Obrazovanje učiteljica u slovenskim i hrvatskim zemljama Austro-Ugarske Monarhije - komparativna analiza
}

\author{
MONIKA GOVEKAR-OKOLIŠ \\ Filozofska fakulteta Univerze v Ljubljani \\ Ljubljana, Slovenija \\ monika.govekar-okolis@guest.arnes.si
}

\begin{abstract}
Rad daje uvid u obrazovanje osnovnoškolskih učiteljica u slovenskim i hrvatskim zemljama Austro-Ugarske Monarhije preko zakonodavstva i organizacije ženskih učiteljskih škola. Istraživanje se sastoji od povijesne komparativne analize razdoblja između 1867. i 1914. godine. Pojavom Dvojne Monarhije dolazi do promjena u obrazovanju učiteljica. One se mogu najprije identificirati na temelju školskoga zakonodavstva. Učiteljice postaju državne službenice. Javljaju se nove državne ženske učiteljske škole, ali i one privatne s pravom javnosti. Analiza zakonodavstva pokazala je razlike između nastavnih planova u učiteljskim školama u slovenskim i hrvatskim zemljama unutar Monarhije. Komparacija njihovih aktivnosti također pokazuje razlike u razvoju, broju i organizaciji. U slovenskim zemljama, koje potpadaju pod austrijsko školsko zakonodavstvo, razvitak četverogodišnjih škola za učiteljice tekao je nešto brže nego u hrvatskim zemljama. Usporedba pokazuje da u slovenskim i hrvatskim zemljama dominiraju privatne škole za učiteljice.
\end{abstract}

Ključne riječi: Austro-Ugarska; obrazovanje učiteljica; žensko školsko zakonodavstvo; ženske učiteljske škole; slovenske i hrvatske zemlje

\section{$\operatorname{Uvod}^{*}$}

Prije 1869. žene koje su željele postati učiteljicama stjecale su potrebna znanja kod časnih sestara u samostanima, u privatnim školama ili kod kuće. Tijekom perioda kojim se bavi ovaj rad, odnosno od pojave dvojne AustroUgarske (1867.) pa do Prvoga svjetskog rata (1914.), u obrazovanje učiteljica

\footnotetext{
* Rad je rezultat istraživanja unutar istraživačkoga projekta Od protomodernizacije do modernizacije hrvatskog školskog sustava u sklopu istraživanja Hrvatskoga instituta za povijest iz Zagreba, koje financira Hrvatska zaklada za znanost pod brojem 4919.
} 
ugrađene su mnoge promjene. Općenito raste mreža škola, povećava se njihovo pohađanje, utemeljena je obaveznost polaska škole, obrazovanje ima sve veći utjecaj na razvoj kulture i opće osviještenosti, a nadležnost nad školama prenijela se s Crkve na državu. To je značilo da uz vjeronauk raste važnost svjetovnoga obrazovanja (građanskoga, domoljubnoga i nacionalnoga). Škole poprimaju jasna obilježja narodnih ustanova kojima upravlja država. Brojni zakoni vezani uz školsku administraciju u slovenskim i hrvatskim zemljama dotaknuli su se organizacije škola, nastavnoga jezika, financiranja, položaja učitelja itd. Uloga učitelja i učiteljskih škola temelji se i razdvaja prema spolu. ${ }^{1}$

Cilj ovoga povijesnoga komparativnog istraživanja usporedba je razvoja obrazovanja osnovnoškolskih učiteljica u slovenskim i hrvatskim zemljama u Austro-Ugarskoj. Analizira se školsko zakonodavstvo koje se odnosi na obrazovanje učiteljica, a uspoređuju se nastavni planovi i osnivanje učiteljskih škola, njihov broj i organizacija ovisno o tome jesu li privatne ili državne. Korištena je deskriptivna istraživačka metoda. ${ }^{2}$ Podaci su prikupljeni sabiranjem i analizom primarnih izvora iz vremena Austro-Ugarske (zakonodavstvo koje regulira obrazovanje, različiti slovenski i hrvatski časopisi koji se bave obrazovanjem i literatura) te korištenjem sekundarnih povijesnih izvora.

Istraživanje se bavi onim područjima u Austro-Ugarskoj koja su u tom razdoblju bila naseljena Slovencima ili Hrvatima. Slovenci su najvećim dijelom živjeli u administrativno podijeljenim područjima (Kranjska, Koruška, Štajerska, Gorica i Gradiška, Istra i Trst) u austrijskoj polovici te manjim dijelom i bez nacionalnih prava na području Zalske i Željezne županije u ugarskom dijelu, ali i u Beneškoj Sloveniji, koja od 1866. pripada Kraljevini Italiji. ${ }^{3}$ Slovenci su imali apsolutnu većinu jedino u Kranjskoj, relativnu u Gorici, a u svim ostalim administrativnim područjima bili su manjina. Istraživanje se bavi ženskim učiteljskim školama na čitavom slovenskom etničkom teritoriju čiji su granični dijelovi danas izvan Republike Slovenije (Klagenfurt, Gorica, Trst). Hrvati su živjeli na djelomično ujedinjenom teritoriju Kraljevine Hrvatske i Slavonije i u Međimurju u ugarskom dijelu te u Dalmaciji i većem dijelu Istre u austrijskom dijelu Austro-Ugarske. ${ }^{4}$ Uz Slovence, sjeverne dijelove Istre naseljavali su Talijani, najvećim dijelom u gradovima na obali. ${ }^{5}$ Istraživanje obuhvaća podatke o ženskim učiteljskim školama u slovenskim zemljama u austrijskom dijelu Austro-Ugarske: Maribor (Štajerska), Klagenfurt (Koruška), Ljubljana i Škofja Loka (Kranjska), Gorica (Gorica i Gradiška), Trst i Koper (Istra) i podatke o ženskim učiteljskim školama u hrvatskim zemljama u ugarskom dijelu: Zagreb, Karlovac, Đakovo, Osijek (Kraljevina Hrvatska i Slavonija), Međimurje (ugarski dio) te u austrijskoj polovici Austro-Ugarske u Pazinu

1 GOVEKAR-OKOLIŠ, The Role of Grammar Schools, 59-65.

2 SAGADIN, Razprave iz pedagoške metodologije, 29.

3 FISCHER et al., Slovenska novejša zgodovina, I. dio, 17-23.

4 O razvitku hrvatskih zemalja u razdoblju dualizma vidi više u sintezi: VALENTIĆ, ČORALIĆ, Povijest Hrvata, knj. 2: Od kraja 15. stoljeća do kraja Prvoga svjetskog rata.

5 ŽONTAR et al., Handbücher und Karten zur Verwaltungsstruktur, 18-198. 
(Istra), kao i u Dubrovniku (Dalmacija). Ovdje su pojmovi „hrvatske” i još više „slovenske” zemlje upitni budući da nisu posve povijesno utemeljeni. Tijekom razdoblja kojim se rad bavi ne postoje političko-administrativne jedinice tih naziva. Koristimo ih radi lakše usporedbe obrazovanja učiteljica u područjima naseljenim slovenskim i hrvatskim življem u drugoj polovini XIX. stoljeća.

Funkcioniranje i organizacija centraliziranoga školskog sustava odvijali su se preko školske administracije koja je bila dijelom državne administracije. U suglasju s onodobnim zakonodavstvom, državna školska tijela imala su ovlast donijeti nastavne planove i standarde, organizirati sustave nadzora nad školama i razvijati školsku mrežu. Kako su prije 1867. na snazi bili različiti zakoni koji se odnose na razna područja, uključujući školstvo, u objema polovicama Austro-Ugarske, a dvojnost je to samo potvrdila, školsko zakonodavstvo mora se sagledavati odvojeno. Nakon Hrvatsko-ugarske nagodbe (1868.) Hrvati u Kraljevini Hrvatskoj i Slavoniji u ugarskom dijelu Monarhije samostalno su upravljali školskim pitanjima. Godine 1874., pod utjecajem austrijskih i ugarskih državnih školskih zakona, donesen je prvi hrvatski školski zakon i osuvremenjen 1888. po pripajanju Vojne krajine Kraljevini Hrvatskoj i Slavoniji. Slijedi analiza zakonodavstva i nastavnih planova za obrazovanje učiteljica u Austro-Ugarskoj, posebno za austrijski, a posebno za ugarski dio.

\section{Zakonodavstvo i nastavni planovi za obrazovanje učiteljica u austrijskom dijelu Austro-Ugarske}

Modernizacija i suštinske promjene osnovne škole, uključujući obrazovanje učiteljica, započele su u planovima reforme javnih škola u Austriji tijekom revolucionarne 1848. godine. ${ }^{6}$ Ipak, ti su planovi najvećim dijelom bili neostvarivi jer su se temeljili na reformi drugih područja, uključujući uvođenje modernih administrativnih općina. Nakon poraza koji je Austrija pretrpjela od Pruske (1866.), a koji je doveo do dvojne podjele Monarhije i zbog kojega je Austrija odbila njemačko ujedinjenje, njemački su liberali preuzeli vodeću ulogu u Beču. ${ }^{7}$ Uvođenjem novih školskih zakona, koji su bili među najvažnijim zahtjevima liberala, osnovno je obrazovanje prvih godina dvojnosti vođeno u liberalnom smjeru. Prije svega Državni zakon od 25. svibnja 1868. donio je osnovne odredbe o odnosu između škole i Crkve, olakšao prijelaz iz crkvenih u svjetovne škole. ${ }^{8}$ Država je preuzela upravljanje i kontrolu nad provedbom obrazovanja u školama, a Crkva je zadržala izravnu kontrolu nad vjeronaukom. Članak 9. Zakona kaže da država ima najveću vlast i kontrolu nad čitavim obrazovnim sustavom preko Ministarstva bogoštovlja i nastave. ${ }^{9}$ Zakon je uveo i princip decentralizacije preko školskih vijeća na tri razine. Članak 10.

\footnotetext{
$6 \quad$ Entwurf der Grundzüge des öffentlichen Unterrichtswesens in Österreich 1848.

VODOPIVEC, Od Pohlinove slovnice do samostojne države, 83.

8 Zakon od 25. svibnja 1868., 97.

9 Isto, 98.
} 
navodi da obrazovanje na zemaljskoj razini administriraju zemaljska školska vijeća, u okruzima okružna te u općinama općinska. Vijeća su nadalje odlučivala o kvantitativnim i kvalitativnim promjenama u obrazovanju učiteljica.

U knjizi Entwurf der Grundzüge des öffentlichen Unterrichtswesens in Österreich iz 1848. pri strukovnim školama planirani su dvogodišnji i trogodišnji tečajevi za obrazovanje učiteljica, iz kojih bi se posljedično razvili seminari za obrazovanje učiteljica. ${ }^{10}$ Kako se 1848 . nije dogodila nikakva velika reforma njihova obrazovanja, buduće su se učiteljice sve do pojave liberalnih školskih propisa kasnih 60-ih godina XIX. stoljeća obrazovale na dvogodišnjim i trogodišnjim tečajevima pri, još uvijek, tzv. normalnim školama (osnovne škole u gradovima) i nekim važnim glavnim školama (osnovne škole u velikim gradovima). Prve javne ženske učiteljske škole (četverogodišnje samostalne srednjoškolske ustanove pod nadležnošću Ministarstva bogoštovlja i nastave) uvodi Narodni školski zakon od 14. svibnja 1869., koji je ujedno standardizirao i profesionalizirao obrazovanje učiteljica. ${ }^{11}$ Zakon je ukinuo prethodnu diferencijaciju osnovnih škola na trivijalne, glavne i normalne uvodeći jedinstvenu osmogodišnju narodnu (osnovnu) školu, koja postaje državnom institucijom, a učiteljice državnim službenicama. Zakon je nadalje propisao osnivanje odvojenih učiteljskih škola za muškarce i žene. ${ }^{12}$

Pojavom ženskih učiteljskih škola otvoren je put djevojkama k učiteljskom pozivu, jednoj od rijetkih intelektualnih profesija za ženu onoga vremena. Zakon je formalizirao jednakost obrazovanja učitelja i učiteljica te osigurao poboljšanje društvenoga statusa mnogih djevojaka koje su postale učiteljice. ${ }^{13}$ Zakon je nadalje odredio da buduće učiteljice moraju imati praktičnu obuku. Svaka ženska učiteljska škola imala je zato „vježbaonicu”, model narodne škole u kojoj su učenice odrađivale praksu. Ženske učiteljske škole morale su se povezati s vrtićima. ${ }^{14} \mathrm{U}$ usporedbi s prethodnim tečajevima za obrazovanje učiteljica pri normalnim i glavnim školama, uvođenjem praćenja poučavanja u narodnim školama i radom u „vježbaonici” zahtjevi postavljeni budućim učiteljicama i njihove kvalifikacije znatno su se popravili kao i kvaliteta njihova rada, koja sada slijedi modernije pedagoške koncepte. Zakon od 14. svibnja 1869. uvodi „ispit zrelosti” na završetku obrazovanja u ženskim učiteljskim školama (polagao se pred povjerenstvom kojim je predsjedao predstavnik zemaljskih školskih vlasti), kojim se stjecala svjedodžba zrelosti. ${ }^{15}$

Isti je zakon propisao nastavni plan za državne ženske učiteljske škole. ${ }^{16}$

${ }^{10}$ Entwurf der Grundzüge des öffentlichen Unterrichtswesens in Österreich 1848, čl. 17. i 58.

11 Zakon od 14. svibnja 1869., čl. 28.

${ }^{12}$ Isto, čl. 26.

13 SCHMIDT, Zgodovina šolstva in pedagogike na Slovenskem, 3. dio, 245-246.

14 Zakon od 14. svibnja 1869., čl. 27.

${ }^{15}$ Isto, čl. 34.

${ }^{16}$ Isto, čl. 29. i 30. 
Tablica 1. Nastavni predmeti u ženskim učiteljskim školama $1869 .{ }^{17}$

\begin{tabular}{|c|l|}
\hline Br. & Nastavni predmeti u ženskim učiteljskim školama \\
\hline 1. & Vjeronauk \\
\hline 2. & Podučavanje i obrazovanje: Povijest obrazovanja i pomoćne discipline \\
\hline 3. & Gramatika: pisani tekstovi i književnost \\
\hline 4. & Geografija i Povijest \\
\hline 5. & Pisanje \\
\hline 6. & Aritmetika (algebra) \\
\hline 7. & Prirodne znanosti (priroda i fizika) \\
\hline 8. & Kućanstvo \\
\hline 9. & Strani jezici \\
\hline 10. & Ženski ručni rad \\
\hline 11. & Risanje \\
\hline 12. & Pjevanje \\
\hline 13. & Tjelovježba za žene \\
\hline 14. & Prema potrebi: poučavanje predškolskog odgoja \\
\hline
\end{tabular}

Prema zakonu iz 1869., učenice su imale četrnaest nastavnih predmeta čija tjedna satnica nije bila određena. Važni su bili Vjeronauk, Podučavanje i obrazovanje: Povijest obrazovanja i pomoćne discipline, Gramatika: pisani tekst i književnost, Geografija i Povijest, Pisanje, Aritmetika (algebra) i Prirodne znanosti (priroda i fizika). Kućanstvo, Strani jezici i Ženski ručni rad poučavani su samo u ženskim učiteljskim školama. Prema potrebi, učenice su poučavane samo predškolskom odgoju i obrazovanju. Uopće, u ženskim je učiteljskim školama bilo manje sadržaja i poučavanja prirodnih znanosti, a više tipično ženskih: Kućanstvo i Ženski ručni rad. Jasno je iz nastavnoga plana da je obrazovanje budućih učiteljica bilo prilagođenu njihovu spolu.

Zakon od 14. svibnja 1869. odredio je da nastavni jezik u učiteljskim školama treba biti materinji, ali je u specifičnim slučajevima odgovornost za primjenu odredbe ostavljena za propisivanje u zemaljskim zakonima. Ako materinji jezik kao nastavni u posebnim školama nije mogao biti određen zemaljskim zakonom, onda ga je određivalo Ministarstvo bogoštovlja i nastave prema savjetu zemaljske školske administracije. ${ }^{18}$ Iako Zakon nije odredio koji je drugi zemaljski jezik, propisao je u istom članku da bi učenici, gdje god je potrebno, morali moći naučiti i drugi zemaljski jezik da bi „mogli poučavati i na tom jeziku ukaže li se potreba”.

Godine 1870. za ženske učiteljske škole donesen je novi nastavni plan. Dopunio je prethodni i odredio broj sati za obavezne i izborne predmete (tablica 2), opet posebno za učenice. ${ }^{19} \mathrm{Uz}$ nastavni jezik (materinji jezik), nastavni plan

\footnotetext{
17 Isto.

18 Isto, čl. 31.

19 „Lehrplan der Bildungsanstalten für Lehrerinnen”, 482-487.
} 
uključio je francuski jezik u obavezne predmete, a u izborne predmete „drugi zemaljski jezik" (učilo ih se 2 sata tjedno u ženskim školama). Engleski jezik učio se samo u ženskim školama, u početku 3 , a zatim 2 sata tjedno. ${ }^{20}$ Godišnja izvješća škola pokazuju da je u slovenskim zemljama nastavni jezik bio njemački. ${ }^{21}$

Nastavni plan za ženske učiteljske škole iz 1870. definirao je broj obaveznih i izbornih nastavnih predmeta (tablica 2). Tijekom sve četiri godine obrazovanja žene su imale 134 sata obaveznih i 17 sati izbornih predmeta, ukupno 151 sat. Obaveznih predmeta bilo je šesnaest. Većina sati bila je posvećena predmetu Nastavni jezik (17 sati), slijedila je Pedagogija s praktičnim vježbama (15 sati) te zatim Aritmetika i Geometrija (14 sati). Manji broj sati bio je posvećen predmetima poput Prirodnih znanosti i Francuskoga jezika (oba 10 sati), Prirodopisa (9 sati), a po 8 sati predmetima Geografija, Povijest i državno zakonodavstvo, Risanje, Pjevanje i Klavir. Najmanji broj sati odlazio je na obavezne predmete Gimnastika (tjelesni odgoj) (4 sata), Pisanje (3 sata) i Kućanstvo (1 sat). Kada se radi o izbornim predmetima (ukupno 17 sati u sve četiri godine obrazovanja), žene su mogle birati između dva predmeta - još jednoga zemaljskog jezika (8 sati) ili Engleskoga jezika (9 sati).

Tablica 2. Tjedna satnica obaveznih i izbornih predmeta u četverogodišnjim ženskim učiteljskim školama u austrijskom dijelu Austro-Ugarske 1870. ${ }^{22}$

\begin{tabular}{|c|c|c|c|c|c|c|}
\hline \multirow[t]{2}{*}{ Br. } & \multirow[t]{2}{*}{$\begin{array}{c}\text { PREDMETI } \\
\text { Obavezni i izborni }\end{array}$} & \multicolumn{4}{|c|}{$\begin{array}{c}\text { ŽENSKE UČITELJSKE } \\
\text { ŠKOLE } \\
\text { Godine/razredi }\end{array}$} & \multirow[t]{2}{*}{$\begin{array}{l}\text { UKUPAN } \\
\text { BROJ sati po } \\
\text { predmetima }\end{array}$} \\
\hline & & 1. & 2. & 3. & 4. & \\
\hline 1. & Vjeronauk & 2 & 2 & 1 & 1 & 6 \\
\hline 2. & Nastavni jezik & 5 & 4 & 4 & 4 & 17 \\
\hline 3. & $\begin{array}{l}\text { Pedagogija s praktičnim } \\
\text { vježbama }\end{array}$ & - & 2 & 5 & 8 & 15 \\
\hline 4. & Prirodopis & 3 & 2 & 2 & 2 & 9 \\
\hline 5. & Prirodne znanosti & 2 & 3 & 3 & 2 & 10 \\
\hline 6. & Geografija & 2 & 2 & 2 & 2 & 8 \\
\hline 7. & Aritmetika i Geometrija & 4 & 4 & 4 & 2 & 14 \\
\hline 8. & Povijest i državno zakonodavstvo & 2 & 2 & 2 & 2 & 8 \\
\hline 9. & Kućanstvo & - & - & - & 1 & 1 \\
\hline 10. & Pisanje & 2 & 1 & - & - & 3 \\
\hline 11. & Risanje & 2 & 2 & 2 & 2 & 8 \\
\hline
\end{tabular}

20 Isto.

${ }^{21}$ STRMČNIK, „O pretečenem in nadaljnem razvoju Zveze društev pedagoških delavcev Slovenije", 407-419.

${ }^{22}$ „Lehrplan der Bildungsanstalten für Lehrerinnen”, 482-487. 


\begin{tabular}{|c|l|cccc|c|}
\hline 12. & Pjevanje & 2 & 2 & 2 & 2 & $\mathbf{8}$ \\
\hline 13. & Klavir & 2 & 2 & 2 & 2 & $\mathbf{8}$ \\
\hline 14. & Gimnastika (tjelesni odgoj) & 1 & 1 & 1 & 1 & $\mathbf{4}$ \\
\hline 15. & Francuski jezik & 3 & 3 & 2 & 2 & $\mathbf{1 0}$ \\
\hline 16. & Ženski ručni rad & 2 & 2 & 1 & - & $\mathbf{5}$ \\
\hline 17. & Drugi zemaljski jezik (izborno) & $(2)$ & $(2)$ & $(2)$ & $(2)$ & $(\mathbf{8})$ \\
\hline 18. & Engleski jezik (izborno) & $(3)$ & $(2)$ & $(2)$ & $(2)$ & $(9)$ \\
\hline Ukupan broj sati (obavezni predmeti) & $\mathbf{3 4}$ & $\mathbf{3 4}$ & $\mathbf{3 3}$ & $\mathbf{3 3}$ & $\mathbf{1 3 4}$ \\
\hline Ukupan broj sati (izborni predmeti) & $\mathbf{5}$ & $\mathbf{4}$ & $\mathbf{4}$ & $\mathbf{4}$ & $\mathbf{1 7}$ \\
\hline
\end{tabular}

Treći austrijski školski zakon koji definira osnovno obrazovanje (1869.) izravno je utjecao na osnivanje četverogodišnjih državnih ženskih učiteljskih škola u austrijskom dijelu Austro-Ugarske i neizravno na razvoj ženskih učiteljskih škola u ugarskom dijelu, u koji je spadala Kraljevina Hrvatska i Slavonija. Car Franjo Josip odobrio je, uz suglasnost Dalmatinskoga sabora, zemaljski školski zakon za Kraljevinu Dalmaciju 29. prosinca 1872. godine. Zakon je prilagodio mnoge odredbe Zakona iz 1869. i propisao da obrazovanje budućih učiteljica ima trajati tri godine. ${ }^{23}$ Dalmatinske ženske učiteljske škole nisu postale četverogodišnje sve do 1904., kada je zemaljski školski zakon usklađen $\mathrm{s}$ državnim. ${ }^{24}$

Zakonodavstvo i nastavni planovi za ženske učiteljske škole $\mathrm{u}$ ugarskom dijelu Austro-Ugarske

Nove državne školske zakone prvi su donosili i potvrđivali u Beču habsburški vladari. Primarno su se ti zakoni primjenjivali u habsburškim zemljama u austrijskom dijelu Austro-Ugarske, a u ugarskom dijelu put primjene bio je nešto duži. Naime, zakoni su morali biti prilagođeni ugarskom pravnom poretku i političkim okolnostima. Prvi austrijski zakon za osnovne škole (1774.) prilagođen je za ugarski dio Carstva (Ratio educationis, 1777.), a odredbe su prilagođene različitim jezičnim, vjerskim i drugim uvjetima u Ugarskoj. ${ }^{25}$

U ugarskom je dijelu razvoj škola, koji se na početku utemeljenja centralizirane državne škole zrcalio posebice u širenju školske mreže i obuci učiteljica, od početka zaostajao za austrijskim dijelom. U Kraljevini Hrvatskoj i Slavoniji, koja Hrvatsko-ugarskom nagodbom dobiva autonomiju u obrazovanju, pravne odredbe koje se tiču produživanja obrazovanja učiteljica slijedile su austrijski sustav preparandijalnih tečajeva sve do 1860 -ih, a nakon toga Liberalni školski zakon od 14. svibnja 1869., osnivanjem ženskih trogodišnjih i

\footnotetext{
${ }^{23}$ Zakon od 29. prosinca 1871., 20, čl. 3.

${ }^{24}$ Zakon od 2. svibnja 1904., 35, čl. 1.

${ }^{25}$ HORBEC, MATASOVIĆ, ŠVOGER, Od protomodernizacije do modernizacije školstva u Hrvatskoj.
} 
četverogodišnjih državnih učiteljskih škola. Potvrdivši Politički ustroj škole u austrijskom dijelu Austro-Ugarske početkom XIX. stoljeća, car Franjo II. ostavio je metodičko-didaktički nadzor osnovne škole na nižoj i srednjoj razini u rukama Crkve. ${ }^{26}$ Škole u ugarskom dijelu tek su neizravno pod utjecajem toga zakonodavstva, no ono se izravno primjenjivalo na školski sustav u Vojnoj krajini, gdje su austrijski propisi na snazi do njezina pripajanja Kraljevini Hrvatskoj i Slavoniji (1881.) i donošenja novoga školskog zakona (1888.). Odredbe trećega državnoga narodnoga školskog zakona (1869.) prilagođene su 1871. za područje Vojne krajine Propisom o nastavi u pučkih učionah Vojne krajine, u kojem se obrazovanje učiteljica ne spominje. ${ }^{27}$

U ugarskom dijelu Monarhije, slijedeći primjer austrijskoga dijela s njemačkim jezikom, pokušalo se uvesti mađarski kao nastavni jezik na svim razinama. Čak i prije 1848. stalno su izbijali politički sukobi oko toga koji će jezik biti službeni. Na temelju dekreta o školskoj reformi koji je donio ugarski parlament i vladareve potvrde prijedloga, donesen je 1845. novi školski zakon Systema scholarum elementarium za ugarski dio Monarhije. ${ }^{28}$ Zakon je zrcalio snažan utjecaj Crkve. Usredotočio se na vjeronauk, a svećenstvo je imalo izravan nadzor nad školama. Nastavni je jezik bio materinji, ali posebna se pozornost pridavala mađarskom jeziku. Propisan je dvogodišnji preparandijalni tečaj za učiteljice, a prilikom zapošljavanja kandidatkinje su imale priložiti primjerene svjedodžbe. U Kraljevini Hrvatskoj i Slavoniji zakon nije provođen do 1848., a tijekom neoapsolutizma (1851. - 1859.) nije imao potpunu pravnu valjanost. U cijelosti je stupio na snagu tek nakon 1861. i primjenjivao se do hrvatskoga školskog zakona iz 1874. godine.

Po ustanovljenju Austro-Ugarske i donošenju niza liberalnih zakona ugarska skupština donosi Zakon o pučkim školama, koji je u ugarskom dijelu Monarhije stupio na snagu 8. prosinca 1868. godine. ${ }^{29}$ Taj ugarski zakon nije imao izravnoga utjecaja na škole u Kraljevini Hrvatskoj i Slavoniji jer je nakon Hrvatsko-ugarske nagodbe obrazovanje potpalo u autonomne nadležnosti hrvatskoga Sabora. Spomenuta dva zakona kao temelj za posljedicu su imala sekularizaciju i modernizaciju osnovnih škola u Kraljevini, koje donosi Zakon od 14. listopada 1874. godine. Donijela ga je Hrvatsko-slavonsko-dalmatinska vlada za banovanja Ivana Mažuranića, a potvrdio car Franjo Josip. ${ }^{30}$

Odredbe toga zakona koje se odnose na trogodišnje obrazovanje učiteljskih pripravnica u ženskim učiteljskim školama snažno su utjecale na razvoj ženskih učiteljskih škola u Kraljevini Hrvatskoj i Slavoniji. Nekadašnji preparandijalni tečajevi postaju trogodišnje ženske učiteljske škole (tablica 3). Na

\footnotetext{
${ }^{26}$ Politische Verfassung der deutschen Schulen, deset izdanja koja su između 1806. i 1869. odredila austrijsko osnovno školstvo.

${ }^{27}$ HORBEC, MATASOVIĆ, ŠVOGER, Od protomodernizacije do modernizacije školstva u Hrvatskoj, 39-40, 335-351.

28 Isto, 28, 143-161.

29 Isto, 36.

${ }^{30}$ Isto, 41-42, 353-386.
} 
mjestu nekadašnje samostanske ženske učiteljske škole u Zagrebu javlja se trogodišnja državna ženska učiteljska škola. ${ }^{31}$

Tablica 3. Nastavni plan trogodišnjih ženskih učiteljskih škola u hrvatskim zemljama $1875 .^{32}$

\begin{tabular}{|c|l|c|c|c|c|}
\hline Br. & \multicolumn{1}{|c|}{ NASTAVNI PREDMET } & $\begin{array}{c}\text { Prva } \\
\text { godina }\end{array}$ & $\begin{array}{c}\text { Druga } \\
\text { godina }\end{array}$ & $\begin{array}{c}\text { Treća } \\
\text { godina }\end{array}$ & Ukupno \\
\hline 1. & Vjeronauk & 2 & 2 & 2 & $\mathbf{6}$ \\
\hline 2. & Pedagogija & 3 & 4 & 8 & $\mathbf{1 5}$ \\
\hline 3. & Hrvatski jezik & 6 & 4 & 4 & $\mathbf{1 4}$ \\
\hline 4. & Njemački jezik & 2 & 2 & 2 & $\mathbf{6}$ \\
\hline 5. & Geografija & 2 & 2 & - & $\mathbf{4}$ \\
\hline 6. & Povijest & - & 2 & 2 & $\mathbf{4}$ \\
\hline 7. & Prirodne znanosti & 2 & 2 & - & $\mathbf{4}$ \\
\hline 8. & Fizika & - & 2 & 2 & $\mathbf{4}$ \\
\hline 9. & Matematika & 2 & 2 & 2 & $\mathbf{6}$ \\
\hline 10. & Geometrija i geometrijsko risanje & 2 & 2 & 2 & $\mathbf{6}$ \\
\hline 11. & Krasopis & 1 & - & - & $\mathbf{1}$ \\
\hline 12. & Prostoruko risanje & 2 & 2 & 2 & $\mathbf{6}$ \\
\hline 13. & Pjevanje & 1 & 1 & 1 & $\mathbf{3}$ \\
\hline 14. & Ženski ručni rad & 2 & 2 & 2 & $\mathbf{6}$ \\
\hline 15. & Gimnastika & $\mathbf{2 9}$ & $\mathbf{3 1}$ & $\mathbf{3 1}$ & $\mathbf{9 1}$ \\
\hline Ukupno & & &
\end{tabular}

Nastavni plan iz 1875. za ženske učiteljske škole u hrvatskim zemljama određuje broj nastavnih sati za sve tri godine obrazovanja, ali bez određivanja tjedne satnice obaveznih i izbornih predmeta (tablica 3). Tijekom čitavoga trogodišnjeg obrazovanja učenice su imale 91 sat za sve predmete i ukupno petnaest nastavnih predmeta. Većina sati bila je posvećena nastavnom predmetu Pedagogija (15 sati), slijedi nastava Hrvatskoga jezika (14 sati). Manje vremena (6 sati) posvećivalo se sljedećim predmetima: Vjeronauk, Njemački jezik, Matematika, Geometrija i geometrijsko risanje, Prostoručno risanje, Ženski ručni rad i Gimnastika. Najmanju satnicu imali su Pjevanje (3 sata) i Krasopis (1 sat).

Drugim hrvatskim školskim Zakonom od 31. listopada 1888. sve su učiteljske škole postale četverogodišnje. ${ }^{33}$ Organizacijski ustroj od 17. srpnja 1889. promijenio je organizaciju škola i utjecao na detaljniju razradu nastavnoga plana (tablica 4$).^{34}$

\footnotetext{
31 „Učiteljske škole”, 351-354.

32 BATINIĆ, GAĆINA ŠKALAMERA, Učiteljice i učitelji u Hrvatskoj 1849-2009, 16.

${ }^{33}$ HORBEC, MATASOVIĆ, ŠVOGER, Od protomodernizacije do modernizacije školstva u Hrvatskoj, 424-427; CUVAJ, Građa za povijest školstva, sv. VII, 703-705.

${ }^{34}$ „Učiteljske škole”, 356; usp. Ustrojni štatut za učiteljske škole u kraljevinah Hrvatskoj i Slavoniji, 27 i 41.
} 
Tablica 4. Nastavni plan četverogodišnjih ženskih učiteljskih škola u hrvatskim zemljama $1889 .{ }^{35}$

\begin{tabular}{|c|c|c|c|c|c|c|}
\hline Br. & $\begin{array}{l}\text { NASTAVNI } \\
\text { PREDMET }\end{array}$ & $\begin{array}{c}\text { Prva } \\
\text { godina }\end{array}$ & $\begin{array}{l}\text { Druga } \\
\text { godina }\end{array}$ & $\begin{array}{c}\text { Treća } \\
\text { godina }\end{array}$ & \begin{tabular}{|l|} 
Četvrta \\
godina
\end{tabular} & Ukupno \\
\hline 1. & Vjeronauk & 2 & 2 & 2 & 2 & 8 \\
\hline 2. & $\begin{array}{l}\text { Pedagogija i praktične } \\
\text { vježbe }\end{array}$ & - & 4 & 6 & 9 & 19 \\
\hline 3. & Hrvatski ili srpski jezik & 4 & 3 & 3 & 3 & 13 \\
\hline 4. & Njemački jezik & 2 & 2 & 2 & 2 & 8 \\
\hline 5. & $\begin{array}{l}\text { Geografija, povijest i } \\
\text { ustav }\end{array}$ & 3 & 3 & 3 & 2 & 11 \\
\hline 6. & $\begin{array}{l}\text { Matematika i } \\
\text { geografsko risanje }\end{array}$ & 3 & 3 & 3 & 2 & 11 \\
\hline 7. & Prirodne znanosti & 3 & 2 & 1 & 1 & 7 \\
\hline 8. & Fizika & 2 & 2 & 1 & 1 & 6 \\
\hline 9. & Krasopis & 1 & 1 & - & - & 2 \\
\hline 10. & $\begin{array}{l}\text { Prostoručno risanje i } \\
\text { modeliranje }\end{array}$ & 4 & 2 & 2 & 1 & 9 \\
\hline 11. & Glazba i pjevanje & 2 & 2 & 1 & 2 & 7 \\
\hline 12. & Kućanstvo* & $\begin{array}{c}\text { nema } \\
\text { podataka }\end{array}$ & $\begin{array}{c}\text { nema } \\
\text { podataka }\end{array}$ & $\begin{array}{c}\text { nema } \\
\text { podataka }\end{array}$ & $\begin{array}{c}\text { nema } \\
\text { podataka }\end{array}$ & 2 \\
\hline 13. & Ženski ručni rad ${ }^{*}$ & $\begin{array}{c}\text { nema } \\
\text { podataka }\end{array}$ & $\begin{array}{c}\text { nema } \\
\text { podataka }\end{array}$ & $\begin{array}{c}\text { nema } \\
\text { podataka }\end{array}$ & $\begin{array}{c}\text { nema } \\
\text { podataka }\end{array}$ & 11 \\
\hline 14. & Gimnastika & 2 & 2 & 1 & 1 & 6 \\
\hline 15. & Sviranje gusli (izborno) & $(2)$ & $(2)$ & $(2)$ & $(2)$ & $(8)$ \\
\hline \multicolumn{2}{|c|}{ Ukupno sati (obavezno) } & 28 & 28 & 25 & 26 & 107 \\
\hline \multicolumn{2}{|c|}{ Ukupno sati (izborno) } & 2 & 2 & 2 & 2 & 8 \\
\hline \multicolumn{2}{|c|}{ Ukupan broj sati } & 30 & 30 & 27 & 28 & 115 \\
\hline
\end{tabular}

* Poučavalo se i nastavne predmete Kućanstvo (2 sata tjedno) i Ženski ručni rad $(11 \text { sati tjedno })^{36}$, ali ne postoje precizni podaci o broju sati za te predmete prema godinama obrazovanja.

Tablica 4 donosi broj propisanih sati za svaku godinu obrazovanja za obavezne i izborne nastavne predmete u četverogodišnjim ženskim učiteljskim školama. Budući da nema podataka za satnicu za svaku godinu obrazovanja za predmete Kućanstvo i Ženski ručni rad, ukupan broj nastavnih sati nije mogao biti iskazan. Za te nastavne predmete postoje podaci samo za ukupni broj nastavnih sati tjedno. Tijekom sve četiri godine obrazovanja učenice su imale 107 sati obaveznih i 8 sati izbornih predmeta (ukupno 115). Nastava je obuhvaćala četrnaest obaveznih predmeta. Većim dijelom obrazovanje je bilo posvećeno

\footnotetext{
35 „Učiteljske škole”, 356-357.

${ }^{36}$ Isto.
} 
nastavnom predmetu Pedagogija i praktične vježbe (19 sati) i Hrvatskom ili srpskom jeziku (13 sati). Slijede predmeti sa satnicom od 11 sati: Geografija, povijest i ustav, Matematika i geografsko risanje i Ženski ručni rad. Najmanju satnicu od obaveznih nastavnih predmeta (po 6 sati) imali su Fizika i Gimnastika. Učenice su mogle birati samo jedan izborni predmet (sa satnicom od 8 sati tijekom sve četiri godine školovanja) - Sviranje gusli. Vježbaonica gdje su učenice mogle izvoditi nastavu ne postoji do Zakona iz 1888. godine. Taj je zakon propisao i završni ispit zrelosti.

Komparacija obrazovnoga zakonodavstva i nastavnih planova za ženske učiteljske škole

Nastavni plan za ženske učiteljske škole, koji je na temelju trećega austrijskoga državnog zakona (1869.) propisao detaljniji kurikul (1870.) za austrijski dio Austro-Ugarske, može se uspoređivati s nastavnim planom za ženske učiteljske škole u Kraljevini Hrvatskoj i Slavoniji (1889.), koji je propisan za hrvatske zemlje ugarskoga dijela Monarhije na temelju hrvatskoga zakona o pučkim školama i obrazovanju učitelja iz 1888. i kojim su u Kraljevini uvedene četverogodišnje učiteljske škole. Za to vrijeme ženske učiteljske škole u Dalmaciji, to jest $\mathrm{u}$ austrijskom dijelu Austro-Ugarske, još uvijek su trogodišnje u skladu s dalmatinskim zemaljskim zakonom koji je na snazi do 1904 . godine.

Razlike između nastavnih planova unutar Austro-Ugarske zrcalile su, prema tome, razlike u zakonodavstvu. Austrijski je dio bio napredniji od ugarskoga (hrvatskoga) u smislu uvođenja naprednih promjena. U Kraljevini Hrvatskoj i Slavoniji zadržane su regionalne specifičnosti, a austrijski su zakoni primijenjeni kasnije. Iako se austrijski nastavni planovi za ženske učiteljske škole javljaju znatno prije od onih u Kraljevini Hrvatskoj i Slavoniji, bili su detaljniji i bolje prilagođeni.

Usporedba austrijskoga nastavnog plana (1870.) za četverogodišnje ženske učiteljske škole (tablica 2) i nastavnoga plana (1889.) za četverogodišnje ženske učiteljske škole u Kraljevini Hrvatskoj i Slavoniji (tablica 4) pokazuje razlike u broju obaveznih i izbornih predmeta. Razlika je upravo u broju obaveznih predmeta kojih je u austrijskom nastavnom planu (1870.) ukupno šesnaest, a u hrvatsko-slavonskom (1889.) ih je četrnaest. Usporedba obaveznih predmeta nadalje pokazuje da ih austrijski ima dva više (Francuski jezik i Klavir) od hrvatsko-slavonskoga, koji ne sadržava ta dva predmeta. Predmeti iz istih područja imaju različite nazive u ženskim učiteljskim školama. Austrijski nastavni plan među obaveznim predmetima ne naglašava koji je nastavni jezik, ostavljajući odluku o tome zemaljskim vlastima. Nastavni plan za Kraljevinu Hrvatsku i Slavoniju s druge strane određuje hrvatski ili srpski kao obavezni nastavni jezik uz njemački jezik.

Usporedba nastavnih planova pokazuje razlike u broju sati nastavnih predmeta (maksimalni i minimalni broj sati nastave). Austrijski nastavni 
plan (1870., tablica 2) ima 10 i više sati nastave za pet obaveznih predmeta: Nastavni jezik (17 sati), Pedagogija s praktičnim vježbama (15 sati), Aritmetika i Geometrija (14 sati), Prirodne znanosti i Francuski jezik (oba po 10 sati). Nastavni plan u Kraljevini Hrvatskoj i Slavoniji (1889., tablica 4) imao je 10 i više nastavnih sati također za pet obaveznih predmeta: Pedagogija i praktične vježbe (19 sati), Hrvatski ili srpski jezik (13 sati), Geografija, povijest i ustav, Matematika i geografsko risanje te Ženski ručni rad (11 sati). Četiri sata više za predmete Pedagogija i Hrvatski ili srpski jezik ne nalazimo u austrijskom nastavnom planu iz 1870. godine. Najmanji broj sati u tom austrijskom nastavnom planu imali su sljedeći obavezni nastavni predmeti: Gimnastika (tjelesni odgoj) (4 sata), Pisanje (3 sata) i Kućanstvo (1 sat). Nastavni plan za Hrvatsku i Slavoniju propisuje najmanju satnicu za dva nastavna predmeta: Fizika (6 sati) i Gimnastika (6 sati). Razlike su vidljive i u broju sati za izborne predmete. Austrijski nastavni plan ima dva izborna predmeta: Drugi zemaljski jezik (8 sati) i Engleski jezik (9 sati), a onaj na snazi u Hrvatskoj i Slavoniji ima jedan izborni predmet: Sviranje gusli (8 sati).

U ženskim učiteljskim školama nailazimo na više nastavnih predmeta iz tipično ženskih područja: Kućanstvo i Ženski ručni rad. Iz nastavnih planova jasno je vidljivo da je obrazovanje budućih učiteljica prilagođeno njihovu spolu.

Razvoj i organizacija ženskih učiteljskih škola u slovenskim i hrvatskim zemljama

Općenito su od početka austrijskoga državnoga školskog sustava 1869. školske vlasti bile svjesne da su, uz dobru organizaciju i materijalne uvjete, za razvoj osnovnih škola potrebni dobri učitelji. Njihovo obrazovanje moralo je biti usklađeno s onodobnim obrazovnim uvjetima. Kako se postupno nužno povećavala složenost njihova znanja i vještina, usporedno se povećavalo i vrijeme trajanja njihova obrazovanja. Posebice u austrijskom dijelu Austro-Ugarske ti su zahtjevi snažno prisutni najmanje od 1848., a realizacija je omogućena trećim školskim zakonom iz 1869. godine. Taj je zakon potpuno odvojio rad učitelja od onoga koji je provodila Crkva (župnici i orguljaši) i prenio je nadzor nad pedagoškim radom sa svećenika na svjetovnjake i školska vijeća. Širenje mreže ženskih učiteljskih škola u slovenskim i hrvatskim zemljama uvelike je ovisilo o sposobnosti ministara obrazovanja koji su propisivali obrazovnu politiku. Usprkos pravnim odredbama koje su bile na snazi, prijelaz na četverogodišnje ženske učiteljske škole u austrijskom dijelu Monarhije nije bio ujednačen jer su uz Dalmaciju i u nekim dijelovima slovenskih zemalja ženske učiteljske škole u početku trajale samo tri godine. Pravni zahtjevi u praksi su prilagođavani uvjetima u pojedinoj zemlji. 


\section{Razvoj ženskih učiteljskih škola u slovenskim zemljama}

Uvođenje novoga nastavnog plana za ženske učiteljske škole (1869.), koji propisuje četverogodišnje obrazovanje, razlikovalo se od područja do područja, od škole do škole. Prijelaz na četverogodišnje školovanje nije se u svim školama dogodio istovremeno. Slično je bilo i s privatnim ženskim učiteljskim školama - nisu sve u isto vrijeme dobile pravo javnosti.

\section{Štajerska}

Nakon 1892. u Mariboru postoji privatna ženska učiteljska škola koju su otvorile katoličke redovnice iz reda školskih sestara. Pravo javnosti dobila je 1896. godine.$^{37}$ Godine 1902. u Mariboru je osnovana i državna četverogodišnja ženska učiteljska škola. ${ }^{38}$

\section{Koruška}

Državna ženska učiteljska škola osnovana je u Klagenfurtu (Koruška) 1869., ali nije uvela četverogodišnji program do $1872 . / 73$. godine. ${ }^{39}$ Kao posljedica financijskih rezova škola je ukinuta 1881. godine. ${ }^{40}$ Godine 1899. uršulinke otvaraju privatnu samostansku žensku učiteljsku školu. ${ }^{41}$

\section{Kranjska}

Četverogodišnja ženska učiteljska škola u Ljubljani otvorena je 25. kolovoza 1871. po dekretu Ministarstva bogoštovlja i nastave. ${ }^{42}$ U Kranjskoj su djelovale i dvije privatne ženske učiteljske škole koje su vodile sestre uršulinke: u Ljubljani (1869.), koja pravo javnosti stječe 1902., i u Škofjoj Loki (1909.), koja pravo javnosti stječe 1910. godine. ${ }^{43}$

\section{Gorica i Gradiška}

Uršulinski samostan imao je privatnu žensku učiteljsku školu u Gorici od 1862. nadalje. ${ }^{44}$ Četverogodišnja državna ženska učiteljska škola u Gorici osnovana je 1874./75. godine.

\footnotetext{
37 Kronika materne hiše šolskih sester v Mariboru 1864 - 1919, 608-609.

38 STRMČNIK, „Razvoj izobraževanja osnovnošolskega učiteljstva na Slovenskem”, 344-346.

39 BRAUMÜLLER, „Die Entwicklung der Klagenfurter Lehrerbildungsanstalt seit 1869”, 30-33.

40 Isto, 40-42.

41 HOJAN, Žensko šolstvo in delovanje učiteljic na Slovenskem, 35.

${ }^{42}$ ČOPIČ, Sto let ljubljanskega učiteljišča, 13.

${ }^{43}$ HOJAN, „Žensko šolstvo in učiteljstvo na Slovenskem v preteklih stoletjih”, 69-70.

${ }^{44}$ HOJAN, Žensko šolstvo in delovanje učiteljic na Slovenskem, 35.
} 
Trst

U Trstu je isprva postojala privatna samostanska ženska učiteljska škola (vodile su ju sestre benediktinke), koja je 1854. imala osam učenica. Benediktinke su održavale dvogodišnje tečajeve. Buduće su učiteljice polagale ispite pred državnim povjerenstvom. ${ }^{45}$ Godine 1872 . postojala je ženska učiteljska škola sa 33 učenice, a nastavni jezik bio je talijanski. ${ }^{46}$ Zbog nedovoljnog broja učenica i visokih troškova povezanih s uvođenjem četverogodišnjega programa ženska učiteljska škola ukinuta je 1875 . godine. ${ }^{47}$ Učenice su mogle nastaviti svoje obrazovanje u učiteljskoj školi u Kopru.

Istra

Slovenske učiteljice iz Kopra (Istra) polazile su žensku učiteljsku školu u Gorici. Postala je četverogodišnja 1874./75. godine. ${ }^{48}$

O osnivanju ženskih učiteljskih škola i uvođenju četverogodišnjega nastavnog plana u slovenskim zemljama odlučivalo je Ministarstvo bogoštovlja i nastave, s iznimkom prostora gdje su na odluku o tome utjecale inicijative pojedinaca ili lokalni čimbenici. Slijedeći zahtjeve za ujednačeniju organizaciju ženskih učiteljskih škola i nastavnih planova, Ministarstvo je formiralo posebno povjerenstvo koje je bilo odgovorno za promjene i poboljšanja ženskih učiteljskih škola. Godine 1874. povjerenstvo je donijelo Organizacijski propis za ženske učiteljske škole, koji se počeo provoditi 1874./75. godine. ${ }^{49}$ Propis je donio novu definiciju ženskih učiteljskih škola, koje postaju obavezne osposobiti učiteljice za ispunjavanje svih zahtjeva koje propisuje državni zakon o osnovnom obrazovanju (u smislu stručnih i općih znanja i njihova karaktera). ${ }^{50}$ Odredbe koje se odnose na trajanje obrazovanja, javnu prirodu škola i neplaćanje školarina, kao i nastavni jezik, ostale su nepromijenjene. Dostupnost obrazovanja za poziv učiteljice poboljšana je preparandijalnim razredima (do 1873. mogli su biti organizirani samo pri ženskim učiteljskim školama, a nakon stupanja na snagu Propisa i pri drugim školama). Pripremni su razredi omogućili učenicama da upišu žensku učiteljsku školu iz različitih škola. To je bila mjera kojom se nastojalo nadoknaditi manjak učiteljskoga kadra. ${ }^{51} \mathrm{U}$ skladu sa Zakonom iz 1896., privatne ženske učiteljske škole dobile su mogućnost javne akreditacije. To je značilo da rade uz uvjet da je ministar odobrio njihov statut i nastavni plan. Nadalje, završni ispit morao se polaga-

${ }^{45}$ HOJAN, „Žensko šolstvo in učiteljstvo na Slovenskem v preteklih stoletjih”, 69.

${ }^{46}$ FRANKOVIĆ et al., Povijest školstva i pedagogije u Hrvatskoj, 148-149.

${ }^{47}$ MARKELJ, Bericht der k.k. Lehrerbildungs-Anstalt, 22.

${ }^{48}$ STRMČNIK, „Razvoj izobraževanja osnovnošolskega učiteljstva na Slovenskem”, 344-346.

49 „Verordnung des Ministers für Cultus und Unterricht vom 26. Mai 1874”, 119-123.

${ }^{50}$ Isto.

${ }^{51}$ Isto. 
ti pod nadzorom inspektora, koji se morao složiti s izdavanjem završne svjedodžbe. Privatne ženske učiteljske škole radile su u skladu s jednakim standardima kao državne. ${ }^{52}$

\section{Razvoj ženskih učiteljskih škola u hrvatskim zemljama}

\section{Kraljevina Hrvatska i Slavonija}

Ženska učiteljska škola otvorena je 1848. u samostanu sestara milosrdnica u Zagrebu, a pravo javnosti ima od 1852. godine. ${ }^{53}$ Od 1864./65. pa sve do 1874. u Đakovu djeluje i samostanska ženska privatna dvogodišnja škola. ${ }^{54}$ Državna ženska učiteljska škola otvara se u Zagrebu 1875., ali je ukinuta 1884. godine. Od tada su žene u Zagrebu mogle pohađati jedino samostansku učiteljsku školu sestara milosrdnica. Godine 1875. otvara se privatna srpska učiteljska škola, koja je pravo javnosti dobila 1911. godine. U Osijeku se 1909./10. otvara državna ženska učiteljska škola, a nalazila se u istoj zgradi kao i državna muška učiteljska škola. ${ }^{55}$

\section{Medimurje}

Međimurje je administrativno pripadalo ugarskoj Zalskoj županiji i ugarskom ministarstvu obrazovanja u Budimpešti i u njemu nije djelovala nijedna ženska učiteljska škola. ${ }^{56}$

Istra

Učiteljice iz Istre pohađale su učiteljske škole u Gorici ili Dubrovniku. Prva hrvatska privatna ženska učiteljska škola u Istri osniva se 1912. u Pazinu. ${ }^{57}$

\section{Dalmacija}

Godine 1875. osnovana je državna ženska učiteljska škola u Dubrovniku. Bila je dvojezična - na hrvatskom i talijanskom jeziku. Godine 1904./05. učiteljske škole u Dalmaciji postaju četverogodišnje. ${ }^{58}$

\footnotetext{
52 KLEIN, Privatschulen im kanonistischen Kontext, 102.

53 ŽUPAN, „The Position of Female Teachers in the Educational System of Croatia (18681918)”, 56-57; BATINIĆ, RADEKA, „The development and prospects of teacher education in Croatia”, 47; OGRAJŠEK GORENJAK, „Otvaranje ženskog liceja u Zagrebu”, 147-148.

54 „Učiteljske škole”, 353; ŽUPAN, „Školovanje učiteljica”, 158.

55 BATINIĆ, GAĆINA ŠKALAMERA, Učiteljice i učitelji u Hrvatskoj 1849-2009, 55; ŽUPAN, „The Position of Female Teachers in the Educational System of Croatia (1868-1918)”, 56-57.

${ }^{56}$ BATINIĆ, GAĆINA ŠKALAMERA, Učiteljice i učitelji u Hrvatskoj 1849-2009, 52-54.

57 Isto, 56.

58 Zakon od 2. svibnja 1904., 35, čl. 1.; BATINIĆ, RADEKA, „The development and prospects of teacher education in Croatia”, 48; ŽUPAN, „The Position of Female Teachers in the Educational System of Croatia (1868-1918)", 57.
} 
Usporedna analiza razvoja, broja i organizacije ženskih učiteljskih škola u slovenskim i hrvatskim zemljama između 1869. i 1914. godine

Tablica 5 sažima u radu iznesene podatke i kronološki i usporedivo prikazuje ženske učiteljske škole u slovenskim i hrvatskim zemljama unutar obrađenog razdoblja. Analizira se razvoj i broj ženskih učiteljskih škola i njihova organizacija po vrsti (privatne ili državne). U skladu s promjenama u zakonodavstvu i broju škola, analizirano razdoblje dijeli se na vrijeme prije 1875. i razdoblje nakon 1909. godine. Ta podjela omogućava bolju usporedbu među područjima.

Tablica 5. Razvoj, broj i organizacija ženskih učiteljskih škola u slovenskim i hrvatskim zemljama između 1869. i 1914.

\begin{tabular}{|c|c|c|c|c|}
\hline & $\begin{array}{c}\text { Ženske učiteljske škole } \\
\text { 1869. - 1914. }\end{array}$ & $\begin{array}{c}\text { Broj škola } \\
\text { do } 1875 . \\
\text { (privatne i } \\
\text { državne) }\end{array}$ & $\begin{array}{l}\text { Broj škola } \\
\text { nakon } \\
1909 . \\
\text { (privatne i } \\
\text { državne) }\end{array}$ & \begin{tabular}{|c} 
Ukupan \\
broj škola \\
od 1869. \\
do 1914. \\
(privatne i \\
državne)
\end{tabular} \\
\hline \multicolumn{5}{|c|}{$\begin{array}{l}\text { SLOVENSKE ZEMLJE (AUSTRIJSKI DIO } \\
\text { AUSTRO-UGARSKE) }\end{array}$} \\
\hline Štajerska & $\begin{array}{l}\text { Maribor, ženska učiteljska privatna } \\
\text { škola školskih sestara (1892.); pravo } \\
\text { javnosti } 1896 . \\
\text { Maribor, četverogodišnja ženska } \\
\text { državna škola (1902.) }\end{array}$ & - & $\begin{array}{c}2 \\
(1 \text { državna, } \\
1 \text { privatna })\end{array}$ & $\begin{array}{c}2 \\
(1 \text { državna, } \\
1 \text { privatna })\end{array}$ \\
\hline Koruška & $\begin{array}{l}\text { Klagenfurt, trogodišnja ženska } \\
\text { državna škola (1869. - 1881.); od } \\
\text { 1872./73. četverogodišnja } \\
\text { Klagenfurt, ženska privatna škola } \\
\text { kod uršulinki (1899.) }\end{array}$ & $\begin{array}{c}1 \\
\text { (državna) }\end{array}$ & $\begin{array}{c}2 \\
(1 \text { državna, } \\
1 \text { privatna })\end{array}$ & $\begin{array}{c}2 \\
(1 \text { državna, } \\
1 \text { privatna })\end{array}$ \\
\hline Kranjska & $\begin{array}{l}\text { Ljubljana, ženska privatna škola } \\
\text { kod uršulinki (1869.); pravo javnosti } \\
1902 . \\
\text { Ljubljana, četverogodišnja ženska } \\
\text { državna škola (1871.) } \\
\text { Škofja Loka, ženska privatna škola } \\
\text { kod uršulinki (1909.); pravo javnosti } \\
1910 . \\
\end{array}$ & $\begin{array}{c}2 \\
(1 \text { državna, } \\
1 \text { privatna })\end{array}$ & $\begin{array}{c}3 \\
\text { (1 državna, } \\
2 \text { privatne) }\end{array}$ & $\begin{array}{c}3 \\
(1 \text { državna, } \\
2 \text { privatne })\end{array}$ \\
\hline $\begin{array}{l}\text { Gorica i } \\
\text { Gradiška }\end{array}$ & $\begin{array}{l}\text { Gorica, ženska privatna škola kod } \\
\text { uršulinki (1862.) } \\
\text { Gorica, četverogodišnja ženska } \\
\text { državna škola od 1874./75. }\end{array}$ & $\begin{array}{c}2 \\
(1 \text { državna, } \\
1 \text { privatna })\end{array}$ & $\begin{array}{c}2 \\
(1 \text { državna, } \\
1 \text { privatna })\end{array}$ & $\begin{array}{c}2 \\
(1 \text { državna, } \\
1 \text { privatna })\end{array}$ \\
\hline
\end{tabular}




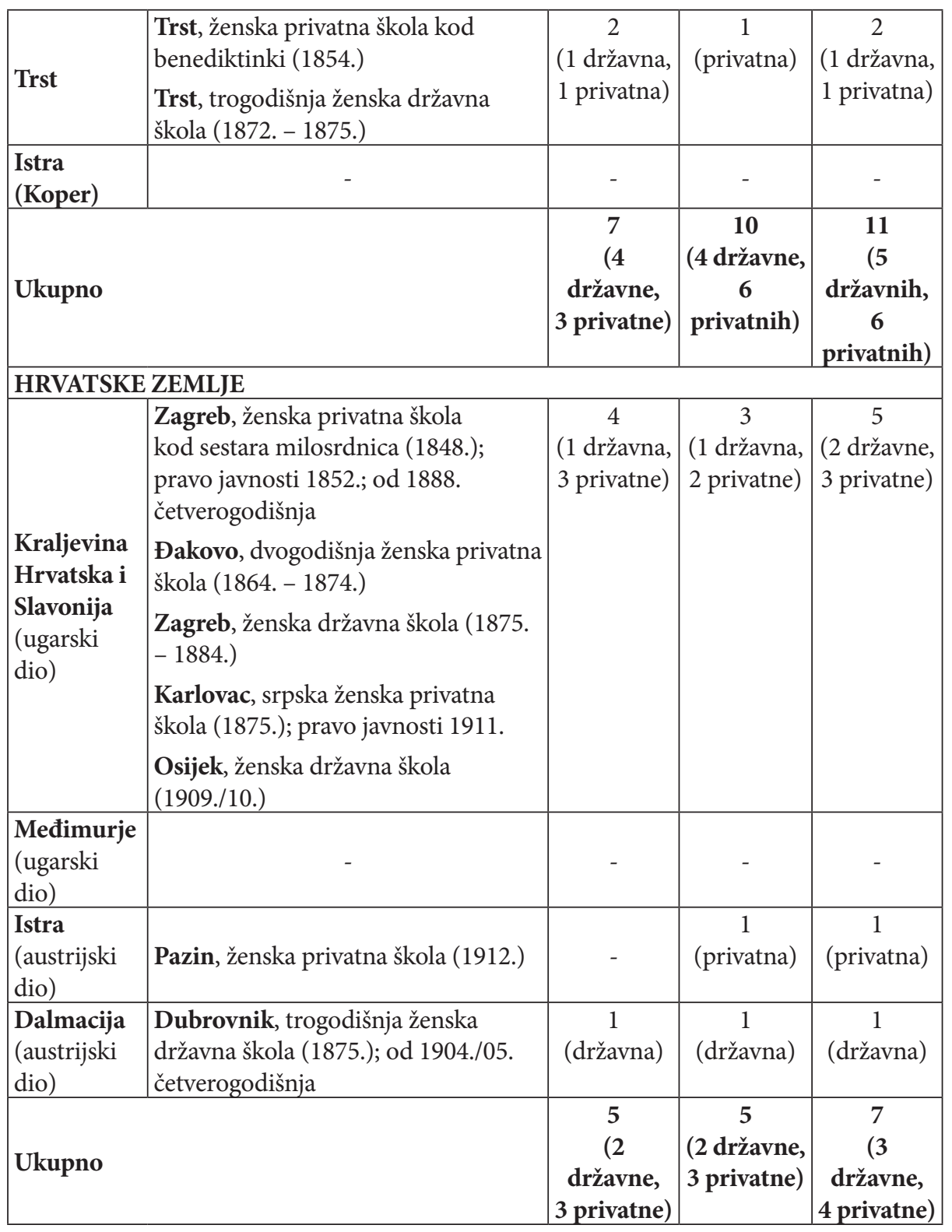

Usporedba s obzirom na razvoj po godinama trajanja i broju ženskih učiteljskih škola (tablica 5) pokazuje da ih između 1869. i 1914. u slovenskim zemljama djeluje ukupno jedanaest, a u hrvatskim zemljama sedam. Najviše škola u slovenskim zemljama nalazimo u Kranjskoj (3), a manje u Gorici i Gradiški (2), Štajerskoj (2), Koruškoj (2) i Trstu (2). Na području hrvatskih zemalja najviše ih je u Kraljevini Hrvatskoj i Slavoniji (5), a manje u Dalmaciji (1) i Istri (1). Sveukupno je između 1869. i 1875. bilo pet ženskih učiteljskih 
škola na području hrvatskih zemalja i sedam na području slovenskih zemalja. Usporedba slovenskih i hrvatskih zemalja nakon 1909. pokazuje da je u slovenskima ukupno deset ženskih učiteljskih škola. Najviše ih je u Kranjskoj (3), a slijede Gorica i Gradiška (2), Štajerska (2) i Koruška (2) i na kraju Trst (1). U hrvatskim zemljama ukupno je pet učiteljskih škola. Najviše ih je u Kraljevini Hrvatskoj i Slavoniji (3), najmanje u Istri (1) i Dalmaciji (1). Početkom XX. stoljeća u slovenskim zemljama ima deset ženskih učiteljskih škola, a u hrvatskima ih je pet.

Usporedba s obzirom na školsko zakonodavstvo pokazuje da su između 1869. i 1914. ženske učiteljske škole osnivane na temelju školskih zakona, uključujući transformaciju iz trogodišnjih u četverogodišnje škole. Treći školski zakon od 14. svibnja 1869., koji se primjenjivao u austrijskom dijelu AustroUgarske (slovenske zemlje te Istra i Dalmacija od hrvatskih zemalja), propisao je četverogodišnji obrazovni period. Primjena zakona bila je postupna jer je većina ženskih učiteljskih škola bila trogodišnja, a sredinom 1870-ih postaju četverogodišnje. Posljednja zemlja koja je uvela četverogodišnji program bila je Dalmacija 1904./05. godine.

U ugarskom dijelu Austro-Ugarske školski zakon od 14. listopada 1874. za Kraljevinu Hrvatsku i Slavoniju propisao je napuštanje tadašnjih tečajeva za obrazovanje učiteljica i pretvorio ih u trogodišnje ženske učiteljske škole. Četverogodišnji programi uvedeni su donošenjem zakona od 31. listopada 1888. godine. U slovenskim zemljama većina je učiteljskih škola bila četverogodišnja 1870-ih, a u hrvatskim zemljama to se primijenilo 1890-ih. U skladu s Propisom iz 1896., privatne ženske učiteljske škole dobile su pravo stjecanja javnosti.

Usporedba s obzirom na osnivača (državne ili privatne škole) (tablica 5) pokazuje da su u slovenskim zemljama prije 1875. postojale četiri državne i tri privatne samostanske škole. U hrvatskim zemljama bile su dvije državne i tri privatne samostanske škole. Nakon 1909. to se promijenilo zbog zatvaranja škola. U slovenskim zemljama broj privatnih samostanskih škola s pravom javnosti povećao se za tri (ukupno ima 6 privatnih škola), a u hrvatskim zemljama broj privatnih samostanskih škola s pravom javnosti povećao se za dvije (ukupno 3 privatne škole). Nakon 1909. bilo je deset ženskih učiteljskih škola u slovenskim zemljama (4 državne i 6 privatnih), a u hrvatskim zemljama bilo ih je pet (2 državne i 3 privatne). U oba područja između 1869. i 1914. bilo je više privatnih (10) nego državnih (8) ženskih učiteljskih škola. Nakon 1909. broj privatnih škola u slovenskim zemljama narastao je sa tri na šest, a u hrvatskim zemljama ostao je isti (3). Broj ženskih škola u slovenskim se zemljama povećao. Može se opravdano pretpostaviti da se više žena u slovenskim zemljama odlučilo za učiteljsku službu i uglavnom su obrazovane u privatnim učiteljskim školama. 


\section{Rasprava}

Komparativna analiza pokazala je da se obrazovanje učiteljica između 1867. i 1914. u slovenskim i hrvatskim zemljama razlikovalo s obzirom na zakonodavstvo, što je znatno utjecalo na organizaciju obrazovanja. U slovenskim zemljama četverogodišnje ženske učiteljske škole javljaju se mnogo prije nego u hrvatskima. U prvima (slovenskim) Zakon od 14. svibnja 1869. propisao je četverogodišnje trajanje ženskih učiteljskih škola, što se primjenjivalo u Istri, ali ne i u Dalmaciji do 1904. godine. U hrvatskim zemljama u ugarskom dijelu Monarhije Zakon od 14. listopada 1874. najprije propisuje trogodišnje ženske učiteljske programe, a zatim Zakon od 31. listopada 1888. četverogodišnje.

Usporedba nastavnoga plana iz 1869. i promjena koje su se dogodile 1870. za slovenske zemlje, Istru i Dalmaciju i onoga iz 1889. za hrvatske zemlje pokazuje različite propisane nastavne predmete za obrazovanje učiteljica u oba područja. Nastavni plan za ženske učiteljske škole u slovenskim zemljama (1870.) nije među obaveznim predmetima specificirao nastavni jezik jer je ta odluka ostavljena zemaljskim vlastima, a u hrvatskim su zemljama propisani hrvatski ili srpski i njemački jezik (1889.). Usporedba nastavnih planova za ženske učiteljske škole $u$ različitim područjima također pokazuje da nisu propisivali isti broj nastavnih predmeta za djevojke. U oba područja djevojke su učile predmete poput Kućanstva i Ženskoga ručnog rada, ali u hrvatskim zemljama Francuski jezik i Klavir nisu bili među obaveznim predmetima, a Engleski ili Drugi zemaljski jezik nisu bili među izbornim predmetima. Nastavni planovi prilagođeni su potrebama pojedinih područja.

Sljedeća razlika između ženskih učiteljskih škola u slovenskim i hrvatskim zemljama bila je s obzirom na osnivača (državne ili privatne). Privatne škole bile su samostanske i u slovenskim i u hrvatskim zemljama. Najčešće su ishodile pravo javnosti prema kraju XIX. stoljeća. Zbog zatvaranja pojedinih škola razdoblje o kojem je riječ (1869. - 1914.) podijeljeno je na period prije 1875. i nakon 1909. godine. Sve do 1875. u slovenskim zemljama bilo je sedam ženskih učiteljskih škola - četiri državne i tri privatne. U isto vrijeme u hrvatskim zemljama bilo je pet ženskih učiteljskih škola, od kojih su dvije bile državne, a tri privatne. Nakon 1909. ukupni broj ženskih učiteljskih škola u slovenskim zemljama povećao se na deset: četiri su bile državne (jedna državna škola u Trstu je ukinuta, a jedna državna učiteljska škola u Mariboru je nova), a šest privatnih. U hrvatskim je zemljama u usporedbi s prethodnim razdobljem broj ženskih učiteljskih škola ostao isti: dvije državne i tri privatne. Jedna državna ženska učiteljska škola ukinuta je u Zagrebu, a jedna privatna u Đakovu. Nastaju nova državna ženska učiteljska škola u Osijeku i nova privatna ženska učiteljska škola u Pazinu.

Zbog različitoga razvoja ženskoga učiteljskog obrazovanja u prijelaznim periodima razlike između slovenskih i hrvatskih zemalja dovoljno su uočljive i sredinom 1870-ih, kada je u hrvatskim zemljama ukupno manje škola (5) nego u slovenskim zemljama (7). Nakon 1909. ukupni broj škola u slovenskim 
je zemljama rastao (sa 7 na 10), a u hrvatskima je ostao isti (5). Usporedba slovenskih i hrvatskih zemalja opravdava tvrdnju da povećanje broja ženskih učiteljskih škola upućuje na mogućnost povećanoga zapošljavanja žena u učiteljskoj profesiji, posebice u slovenskim zemljama. To je poticalo i zakonodavstvo kada je privatnim učiteljskim školama priznato pravo javnosti da bi ih se izjednačilo s državnim učiteljskim obrazovanjem. Svime time žene su dobile najvišu moguću razinu obrazovanja ${ }^{59}$ onoga vremena, koje ih je dovelo do boljega društvenog položaja u usporedbi sa ženama koje nisu dostigle takav profesionalni stupanj.

\section{Zaključak}

Ovo je prvo komparativno istraživanje u području obrazovanja učiteljica u Austro-Ugarskoj u slovenskim i hrvatskim zemljama i važno je za daljnja povijesna istraživanja. Austrijsko školsko zakonodavstvo kvantitativno je i kvalitativno utjecalo na organizaciju ženskih učiteljskih škola i kvalitetu obrazovanja učiteljica. Pojavile su se četverogodišnje učiteljske škole, privatne ženske učiteljske škole dobivaju pravo javnosti, a učiteljice postaju državne službenice. Između 1867. i 1914. u slovenskim i hrvatskim zemljama obrazovanje učiteljica standardizira se i profesionalizira, iako se u hrvatskim zemljama, u ugarskom dijelu Monarhije, to događa kasnije nego u austrijskom dijelu. Na oba područja između 1869. i 1914. prevladavaju privatne ženske učiteljske škole.

\section{Izvori i literatura}

BATINIĆ, Štefka; GAĆINA ŠKALAMERA, Sonja. Učiteljice i učitelji u Hrvatskoj 1849-2009. Zagreb: Hrvatski školski muzej, 2009.

BATINIĆ, Štefka; RADEKA, Igor. „The development and prospects of teacher education in Croatia”. History of Education \& Children's Literature 8 (2013), br. 1: 43-62.

BRAUMÜLLER, Johann. „Die Entwicklung der Klagenfurter Lehrerbildungsanstalt seit 1869". U: Dritter Bericht der k. $k$. Lehrerbildungsanstalt in Klagenfurt. Klagenfurt: K.k. Lehrerbildungsanstalt, 1882, 1-42.

CUVAJ, Antun. Građa za povijest školstva Kraljevina Hrvatske i Slavonije od najstarijih vremena do danas, sv. VII. Zagreb: Kr. Hrv.-slav.-dalm. zemaljska vlada, Odjel za bogoštovlje i nastavu, 1911.

ČOPIČ, Venceslav. Sto let ljubljanskega učiteljišča. Ljubljana: Gimnazija pedagoške smeri v Ljubljani, 1973.

\footnotetext{
${ }^{59}$ Uz žensku učiteljsku školu, Licej je 90-ih godina XIX. stoljeća bio jedina ženska institucija koja je omogućavala obrazovanje učiteljica. Učenice koje su na Liceju položile završni ispit za pedagoški smjer mogle su se zaposliti kao učiteljice u pučkim školama. Više o tome: OGRAJŠEK GORENJAK, „Otvaranje ženskog liceja u Zagrebu”, 170, 173.
} 
Entwurf der Grundzüge des öffentlichen Unterrichtswesens in Österreich. Wien: Der kaiserlich-königlichen Hof- und Staatsdruckerei, 1848.

FISCHER, Jasna (gl. ur.); BORAK, Neven; ČEPIČ, Zdenko; DEŽELAK BARIČ, Vida; DOLENC, Ervin; FERENC, Tone; GABRIČ, Aleš; GAŠPARIČ, Jure; GODEŠA, Bojan; GUŠTIN, Damijan; VODOPIVEC, Peter. Slovenska novejša zgodovina 1848-1992. Od programa Zedinjena Slovenija do mednarodnega priznanja Republike Slovenije, I. dio. Ljubljana: Mladinska knjiga, 2005.

FRANKOVIĆ, Dragutin; GODLER, Ljubica; LONČAR, Ljubica; OGRIZOVIĆ, Mihajlo; PAZMAN, Dragutin; TUNKL, Antun. Povijest školstva i pedagogije u Hrvatskoj. Zagreb: Pedagoško-književni zbor, 1958.

GOVEKAR-OKOLIŠ, Monika. The Role of Grammar Schools in Forming the National Identity of the Slovenes within Austria from 1849 to 1914. Hamburg: Verlag Dr. Kovač, 2017.

HOJAN, Tatjana. Žensko šolstvo in delovanje učiteljic na Slovenskem. Ljubljana: Slovenski šolski muzej, 1970.

HOJAN, Tatjana. „Žensko šolstvo in učiteljstvo na Slovenskem v preteklih stoletjih". Zbornik za historiju školstva i prosvjete (1968) (1969): 47-81.

HORBEC, Ivana; MATASOVIĆ, Maja; ŠVOGER, Vlasta. Od protomodernizacije do modernizacije školstva u Hrvatskoj: zakonodavni okvir. Zagreb: Hrvatski institut za povijest, 2017. Pristup ostvaren 17. 7.2017. http://histedu.isp. $\mathrm{hr} /$ histedu/wp-content/uploads/2015/07/Institut-MODERNIZACIJA-SKOLSTVA.pdf.

KLEIN, Bernhard. Privatschulen im kanonistischen Kontext - eine staatskirchenrechtliche Bestandsaufnahme. Linz: Universitätsverlag Rudolf Trauner, 1996.

Kronika materne hiše šolskih sester v Mariboru 1864 - 1919. Ljubljana: Kongregacija šolskih sester sv. Frančiška Kristusa Kralja, Mariborska provinca, 2006.

„Lehrplan der Bildungsanstalten für Lehrerinnen. 19. Juli 1870, Z. 7033”. Verordnungsblatt für den Dienstbereich des Ministeriums für Cultus und Unterricht (Wien), 1870, Nr. 112: 482-487.

MARKELJ, Johann. Bericht der k.k. Lehrerbildungs-Anstalt in Capodistria am Schlusse des Schuljahres 1899/1900. Capodistria: Lehrerbildungs-Anstalt, 1900.

OGRAJŠEK GORENJAK, Ida. „Otvaranje ženskog liceja u Zagrebu”. Povijest u nastavi IV (2006), br. 8: 147-176.

Politische Verfassung der deutschen Schulen in den k., auch $k . k$. deutschen Erbstaaten. Wien: Verlag der k.k. Schülbucher, 1806.

SAGADIN, Janez. Razprave iz pedagoške metodologije. Ljubljana: Filozofska fakulteta Univerza v Ljubljani, 1991. 
SCHMIDT, Vlado. Zgodovina šolstva in pedagogike na Slovenskem, 3. dio. Ljubljana: Delavska enotnost, 1988.

STRMČNIK, France. „O pretečenem in nadaljnem razvoju Zveze društev pedagoških delavcev Slovenije”. Sodobna pedagogika (1986), br. 9-10: 407-419.

STRMČNIK, France. „Razvoj izobraževanja osnovnošolskega učiteljstva na Slovenskem v obdobju od leta 1869 do razpada Avstro-Ogrske”. U: Osnovna šola na Slovenskem 1869 - 1969. Ljubljana: Slovenski šolski muzej, 1970, 339-412.

„Učiteljske škole”. U: Školstvo u Hrvatskoj i Slavoniji od njegova početka do konca god. 1895. Sastavljeno po službenim podacima prigodom Milenijske izložbe u Budimpešti godine 1896. Zagreb: Kr. Hrv.-Slav.-Dalm. zem. vlada, 1896.

"Ustrojni štatut za učiteljske škole u kraljevinah Hrvatskoj i Slavoniji”. Zagreb, 1889. U: „Učiteljske škole”. Školstvo u Hrvatskoj i Slavoniji od njegova početka do konca god. 1895. Sastavljeno po službenim podacima prigodom Milenijske izložbe u Budimpešti godine 1896. Zagreb: Kr. Hrv.-Slav.-Dalm. zem. vlada, 1896.

VALENTIĆ, Mirko; ČORALIĆ, Lovorka, ur. Povijest Hrvata, knj. 2: Od kraja 15. stoljeća do kraja Prvoga svjetskog rata. Zagreb: Školska knjiga, 2005.

„Verordnung des Ministers für Cultus und Unterricht vom 26. Mai 1874, z. 7114 an alle Landesschulbehörden, womit ein Organisations-Statut für die Lehrerbildungsanstalten erlassen wird". Verordnungsblatt für den Dienstbereich des Ministeriums für Cultus und Unterricht (Wien), 1874.

VODOPIVEC, Peter. Od Pohlinove slovnice do samostojne države: slovenska zgodovina od konca 18. do konca 20. stoletja. Ljubljana: Modrijan, 2006.

Zakon od 25. svibnja 1868. „wodurch grundsätzliche Bestimmungen über das Verhältnis der Schulle zur Kirche erlassen werden”. Reichs-Gesetz-Blatt für das Kaiserthum Oesterreich (Wien), RGBI 48, Jahrgang 1868.

Zakon od 14. svibnja 1869. „durch welches die Grundsätze des Unterrichtswesens bezüglich der Volksschulen festgestellt werden”. Reichs-GesetzBlatt für das Kaiserthum Oesterreich (Wien), RGBI 62, Jahrgang 1869.

Zakon od 29. prosinca 1871. „wirksam für das Königreich Dalmatien, womit auf Grund des Reichsgesetzes vom 14. Mai 1869 die Absätze ... des bezogenen Gesetzes abgeändert werden”. Landes-Gesetz- und Verordnungsblatt für Dalmatien (Zara), Nr. 11, Jahrgang 1872.

Zakon od 2. svibnja 1904. „wirksam für das Königreich Dalmatien, womit die $\$ \$ 3$ und 4 des Landesgesetzes vom 29. Dezember 1871 aufgehoben werden". Landes-Gesetz- und Verordnungsblatt für das Königreich Dalmatien (Zara), Nr. 16, Jahrgang 1904.

ŽONTAR, Jože; COVA, Ugo; DEMŠAR, Vinko; DORSI, Pierpaolo; FOURNIER, Gernot; SPREITZHOFER, Karl; UMEK, Eva; WADL, Wilhelm. Handbücher und Karten zur Verwaltungsstruktur in den Länder Kärnten, Kra- 
in, Küstenland und Steiermark bis zum Jahre 1918. Graz; Klagenfurt; Ljubljana; Gorizia; Trieste: Steiermärkisches Landesarchiv Graz, 1988.

ŽUPAN, Dinko. „Školovanje učiteljica”. U: Mentalni korzet. Spolna politika obrazovanja žena u Banskoj Hrvatskoj (1868-1918). Osijek; Slavonski Brod: Učiteljski fakultet u Osijeku; Hrvatski institut za povijest, Podružnica za povijest Slavonije, Srijema i Baranje Slavonski Brod, 2013, 158-166.

ŽUPAN, Dinko. „The Position of Female Teachers in the Educational System of Croatia (1868-1918)". U: Women's Education in Southern Europe: Historical Perspectives (19th-20th centuries), sv. III, ur. Antonella Cagnolati i Antonio Francisco Canales Serrano. Roma: Aracne Editrice, 2019, 55-83. 


\section{SAŽETAK}

\section{Obrazovanje učiteljica u slovenskim i hrvatskim zemljama Austro-Ugarske Monarhije - komparativna analiza}

Rad komparativno opisuje obrazovanje osnovnoškolskih učiteljica u slovenskim i hrvatskim zemljama Austro-Ugarske Monarhije preko zakonodavstva i organizacije ženskih učiteljskih škola. Istraživanje se sastoji od povijesne komparativne analize perioda od pojave dvojne Austro-Ugarske (1867.) pa do Prvoga svjetskog rata (1914.). Tijekom toga perioda u obrazovanje učiteljica ugrađene su mnoge promjene. Prije 1869. žene koje su željele postati učiteljicama stjecale su potrebna znanja kod časnih sestara u samostanima, u privatnim školama ili kod kuće. Austrijsko školsko zakonodavstvo 1869. kvantitativno je i kvalitativno utjecalo na razvoj i organizaciju ženskih učiteljskih škola i kvalitetu obrazovanja učiteljica. Učiteljice postaju državne službenice. Analiza zakonodavstva pokazala je razlike između nastavnih planova u učiteljskim školama u slovenskim i hrvatskim zemljama unutar Monarhije. Nastavni planovi prilagođeni su potrebama pojedinih područja. Komparacija njihovih aktivnosti također pokazuje razlike u razvoju, broju i organizaciji. Javljaju se nove državne ženske učiteljske škole, ali i one privatne s pravom javnosti. U slovenskim zemljama, koje potpadaju pod austrijsko školsko zakonodavstvo, razvitak četverogodišnjih škola za učiteljice tekao je nešto brže nego u hrvatskim zemljama. Usporedba pokazuje da su na oba područja dominirale privatne škole za učiteljice i tako se u slovenskim i hrvatskim zemljama obrazovanje učiteljica standardizira i profesionalizira. 